\title{
PRAWDA KONTROLERSKA
}

\begin{abstract}
Streszczenie. Odkrywanie prawdy to niezbywalna cecha każdej praworządnej kontroli i wyraża się poprzez dążenie do urzeczywistnienia prawdy materialnej. Niemniej jednak ustalanie stanu faktycznego częstokroć odbiega od ideału i wiąże się z pewnego rodzaju kreacją rzeczywistości, którą autor nazywa prawda kontrolerska. W artykule opisuje charakterystykę owej prawdy, która jak dotąd nie doczekała się naukowego zbadania. Oto dokonywane w trakcie kontroli ustalenia stanu faktycznego tworzą własną rzeczywistość funkcjonującą w przestrzeni normatywno-semantycznej. Prawda kontrolerska jest w mniejszym lub większym stopniu prawdą subiektywną, niepewną, przybliżoną i uproszczoną, co bynajmniej nie oznacza automatycznie jej kłamliwości. Niedoskonałość obrazu faktów to coś nieodzownego i musi zostać zaakceptowane, choć jednocześnie domaga się zachowania poprawności poznania i opisu. Odpowiednią przestrzenią badawczą do podejmowania elementarnych rozważań o granicach kontrolerskiego poznania prawdy jest filozofia kontroli.
\end{abstract}

Slowa kluczowe: prawda kontrolerska, prawda materialna, prawda obiektywna, prawda formalna, filozofia kontroli, ustalanie stanu faktycznego.

\section{WSTĘP}

Spośród ponad pięćdziesięciu zasad odnoszących się do postępowania kontrolnego ${ }^{2}$, za naczelną uznaje się zasadę prawdy materialnej/obiektywnej. Nazywana bywa wręcz „królową zasad”, zaś pozostałe odgrywają rolę służebną, stanowiąc gwarancję jej realizacji (Padrak 2003, 36; Nowikowska, Cieślak 2015, 189). Należy ona też do zasad najbardziej rozpowszechnionych: 94\% kontrolerów NIK, 75\% kontrolerów Wojewódzkiego Inspektoratu Inspekcji Handlowej w Bydgoszczy oraz 73\% kontrolerów Regionalnej Izby

*Delegatura NIK w Bydgoszczy, Leszek.Murat@nik.gov.pl.

${ }^{1}$ Niektóre zawarte w artykule informacje są chronione tajemnicą kontrolerską; z obowiązku jej zachowania na potrzeby publikacji zostałem zwolniony przez Prezesa NIK 17 stycznia $2019 \mathrm{r}$. (nr sprawy BOE-BOI.0172.008.2019) oraz 30 sierpnia 2019 r. (nr sprawy BOE-BOI.0172.018.2019).

${ }^{2}$ Czterdzieści zasad wymieniłem w artykule: Murat (2017, 47). Lista ta podlega ciągłemu uzupełnianiu, np. o wymienione przez Tomasza Sordyla zasady: odmienności (indywidualności), jednoosobowego kierownictwa, systematyczności, dokładności, przejrzystości i zwięzłości opisu oraz spójności - jako zasady prowadzenia przesłuchań w postępowaniu kontrolnym (Sordyl 2019b, 3, 5, 1516); jak również o wymienione przez tego autora zasady prowadzenia oględzin, m.in.: ekonomiczności oraz zachowania bezpieczeństwa oraz o zasady sporządzania protokołów, m.in.: poprawności językowej, jednolitej terminologii (Sordyl 2019a, 21-22, 28). 
Obrachunkowej w Opolu stwierdziło, że potrafią ją zdefiniować i że wiedza ta wpływa na ich postępowanie ${ }^{3}$. Niemniej jednak zasada prawdy materialnej/ obiektywnej nie doczekała się dotychczas wyczerpującego, odrębnego opisu i wciąż kryje wiele niejasności. Tymczasem w praktyce ustalanie stanu faktycznego wiąże się z pewnego rodzaju kreacją rzeczywistości, którą nazywam - analogicznie do prawdy sądowej - prawdą kontrolerską. Choć pretenduje do odzwierciedlania prawdy, to $z$ natury rzeczy jest niedoskonałym opisem często bardzo złożonych zjawisk, co zademonstruję na prostych przykładach ${ }^{4}$. Stawiam sobie za cel, aby w artykule przedstawić niektóre cechy prawdy kontrolerskiej i żywię nadzieję, że konkluzje zachęcą do dalszych pogłębionych studiów na jej temat. Rozważania ukierunkowuję na działalność Najwyższej Izby Kontroli, aczkolwiek znaczna część spostrzeżeń znajduje zastosowanie do całego systemu kontroli.

\section{ZASADA PRAWDY OBIEKTYWNEJ A ZASADA PRAWDY MATERIALNEJ}

Zanim wprowadzę pojęcie „prawdy kontrolerskiej”, chciałbym pokrótce omówić trzy nazwy, które w nauce prawa tradycyjnie odnoszą się do zagadnienia prawdy: ,prawda materialna”, ,prawda obiektywna” i ,prawda formalna”. Jak się bowiem okazuje, pomimo powszechnego posługiwania się nimi przez jurysprudencję, wciąż nie są wolne od niejasności.

W literaturze prawniczej, w tym poświęconej kontroli, spotkać można dwa zbliżone do siebie wyrażenia: prawda materialna i prawda obiektywna ${ }^{5}$ (często występujące jako określenia zasad prawa). Wskazuje się, że nazwa „prawda materialna" pochodzi z doktryny zachodnioeuropejskiej, natomiast nazwa „prawda obiektywna” wywodzi się z doktryny radzieckiej (Jodłowski, Resich, Lapierre, Misiuk-Jodłowska 1997, 108) ${ }^{6}$. Przez niektórych autorów uznawane są synonimy (np. Ampuła 2014, 24; Antoniak 2012, 106; Nawłoka-Bielecki 1991, 3), inni posługują się jedną z nich bez odnoszenia się do drugiej, jeszcze inni traktują je odmiennie (Jarzęcka-Siwik, Berek, Skwarka, Wrona 2018,

${ }^{3}$ Badanie dotyczyło deklarowanej znajomości łącznie 28 zasad postępowania kontrolnego. Do ośmiu zasad uznanych przez uczestników badania za najbardziej znane należą, obok zasady prawdy materialnej, zasady: niezależności, jawności, fachowości, praworządności, pisemności, bezstronności i legalności. Łącznie w badaniu wzięło udział 96 kontrolerów. Szerzej o wynikach zob. Murat (2017, 49-50).

${ }^{4}$ Zostały one stworzone na potrzeby artykułu i służą wyłącznie ilustracji opisanych zagadnień.

${ }^{5}$ W literaturze spotkać można też wyrażenia ,zasada obiektywizmu”, np. Bolek, Rosińska $(2012,47)$ oraz „zasada obiektywności” np. Kaczyński $(2010,85)$.

${ }^{6} \mathrm{~W}$ zacytowanej monografii nadmieniono też, że pojęcie ,"prawdy obiektywnej” jest niefortunne, albowiem sugeruje istnienie prawdy nieobiektywnej. 
155-157; Kałużny 2016, 128-130)7. Tadeusz Widła i Dorota Zienkiewicz zanotowali, że prawda materialna bywa pojmowana jako „niedoskonały odpowiednik prawdy obiektywnej”, tj. sądów nienagannie, kompletnie obrazujących stan rzeczy (Widła, Zienkiewicz 2005, 93). W tym ujęciu prawda obiektywna jawi się jako ideał zakładający istnienie podmiotu doskonale poznającego i przetwarzającego poznane dane. Tak rozumiana prawda obiektywna nie poddaje się urzeczywistnieniu, stąd realna do osiągnięcia pozostaje jedynie prawda materialna (Widła, Zienkiewicz 2005, 93). Jestem sceptyczny wobec rozróżniania prawdy materialnej i obiektywnej według powyższego kryterium. Pozbawia ono bowiem prawdy materialnej idealistycznego charakteru, który jest podstawową cechą zasad prawa. Dalej będę posługiwał się nazwami „zasada prawdy materialnej” i ,zasada prawdy obiektywnej” zamiennie, również dlatego, że podawane w literaturze definicje posiadają wspólny istotny desygnat: dokonywanie ustaleń zgodnych z rzeczywistością (do tego wątku wrócę nieco dalej). W przypadku NIK, obie wywodzone są też z tego samego przepisu - art. 28 ustawy z dnia 23 grudnia 1994 r. o Najwyższej Izbie Kontroli (Dz.U. z 2019 r., poz. 489 ze zm.), tj. ze sformułowanego expressis verbis obowiązku ustalania stanu faktycznego kontrolowanej działalności. Dopiero pod koniec artykułu, po dokonaniu stosownych objaśnień, zaproponuję kryterium odróżniające je od siebie.

\section{PRAWDA MATERIALNA A PRAWDA FORMALNA}

Zasada prawdy materialnej bywa przeciwstawiana zasadzie prawdy formalnej. Tak kontrastowe ich zestawienie może deprecjonować prawdę formalną, zwłaszcza gdy pozbawione jest odpowiedniego opisu. Niektórzy wręcz pojmują ją w kategoriach kłamstwa. Na przykład Czesław Nawłoka-Bielecki uważał prawdę formalną za „w istocie rzeczy fikcyjną, niezgodną z obiektywną rzeczywistością" i w związku z tym przestrzegał kontrolerów, aby unikali wszystkiego, co mogłoby doprowadzić do jej ustalenia (Nawłoka-Bielecki 1991, 3).

Inny pogląd na temat relacji obu zasad prezentują Łukasz Łukowski i Bartosz Żukowski. Ich zdaniem, obiektywny stan faktyczny jest podstawą orzeczeń zarówno w przypadku stosowania zasady prawdy materialnej jak i zasady prawdy formalnej, a w związku z tym ,z gruntu fałszywe jest, sugerowane w doktrynie, przeciwstawienie rzeczywistego stanu faktycznego, stanowiącego podstawę orzekania zgodnego z zasadą prawdy materialnej, swojego rodzaju preparatowi faktów, służącemu rzekomo za podstawę orzeczeń wydanych w trybie określonym zasadą prawdy formalnej” (Łukowski, Żukowski 2014,

\footnotetext{
${ }^{7}$ Kałużny posługuje się wyrażeniem „zasada obiektywizmu”.
} 
50). Łukasz Łukowski i Bartosz Żukowski przekonują, że oba typy orzeczeń (sądów) ${ }^{8}$ zawierają roszczenie do korespondencji z pozajęzykową rzeczywistością i odnoszą się do tej samej obiektywnie pojętej prawdy. Wobec tego zasada prawdy formalnej bynajmniej nie uprawnia - jak można by intuicyjnie zakładać - do aktywności faktotwórczej, albowiem i tym sądom towarzyszy „stałe domniemanie referencji do rzeczywistości" (Łukowski, Żukowski 2014, 51-52)9. Co więcej, w pewnych okolicznościach może się zdarzyć, że zgodny z rzeczywistością obraz stanu faktycznego zostanie wyłoniony w drodze postępowania zorganizowanego zgodnie z zasadą prawdy formalnej, a nie z zasadą prawdy materialnej (Łukowski, Żukowski 2014, 55).

Jaka jest wobec tego różnica pomiędzy zasadą prawdy materialnej a formalnej? Ciekawy wydaje się pogląd Łukasza Łukowskiego i Bartosza Żukowskiego, że należy jej poszukiwać w odmiennych regułach „tworzenia oraz weryfikacji wartości logicznej sądów składających się na wyłoniony w toku postępowania obraz faktów, służący za podstawę orzekania" (Łukowski, Żukowski 2014, 52). Chodzi o sposób uregulowania uprawnień podmiotów odtwarzających obraz stanu faktycznego: stron postępowania i organu wydającego orzeczenie. W przypadku prawdy formalnej, to strony postępowania rekonstruują rzeczywistość, zaś organ wydający orzeczenie pozostaje w zasadzie bierny ${ }^{10}$. W przypadku prawdy materialnej, aktywny w poszukiwaniu prawdy jest także organ wydający orzeczenie. W rzeczywistości kontrolerskiej podmiotami stosunku kontrolnoprawnego są dwie strony (kontrolujący i kontrolowany) ${ }^{11}$, z tym że spośród nich jedna (kontrolujący) jest jednocześnie organem orzekającym. Ciąży na nim obowiązek aktywnej weryfikacji obrazu prawdy.

Nieco inaczej podział ten przedstawia Rafał Padrak. Według niego zasada prawdy obiektywnej zobowiązuje do badania danego zjawiska w związku przyczynowo-skutkowym z innymi faktami, zaś zasada prawdy formalnej (jako jej przeciwieństwo) wymaga jedynie tego, aby ustalenia stanu faktycznego były zgodne ze zgromadzonym materiałem dowodowym, niezależnie od tego, czy jest on zgodny z rzeczywistością (Padrak 2012, 60). Zauważmy jednak, że materiał dowodowy kontrolera musi potwierdzać ustalenia poczynione w ramach stosowania obu zasad. Jako przykład podam dążenie do poznania prawdy o tym, czy

\footnotetext{
${ }^{8} \mathrm{Tj}$. wypowiedzi sformułowanych w oparciu o zasadę prawdy materialnej i formalnej.

${ }^{9}$ Warto też zwrócić uwagę, że Andrzej Sylwestrzak posługuje się terminem „zasada prawdy”: (Sylwestrzak 2006, 12).

${ }^{10}$ Autorzy twierdzą, że w tym przypadku organ wydający orzeczenie pozbawiony jest możliwości czynnego stosowania kryterium korespondencyjnego i stosuje jedynie kryterium koherencyjne.

${ }^{11}$ Stosunek kontrolnoprawny to uregulowana przez normy prawne relacja pomiędzy dwoma podmiotami, polegająca na tym, że jeden z nich (kontrolujący) uprawniony jest do ustalenia wyznaczeń oraz wykonań drugiego podmiotu, a ten drugi podmiot (kontrolowany) zobowiązany jest umożliwić kontrolującemu realizację tych uprawnień (Murat 2016, 12).
} 
w kontrolowanym instytucie badawczym powołano zastępcę dyrektora do spraw naukowych. Według omawianego tutaj rozumienia zasady prawdy formalnej, wystraczającym dowodem byłby akt powołania, podczas gdy zasada prawdy obiektywnej nakazywałaby znalezienie potwierdzenia powołania zastępcy dyrektora w szerszym kontekście dowodowym (choćby poprzez analizę listy płac, pobranie wyjaśnień od pracowników instytutu, itp.). Jak z tego widać, zasada prawdy obiektywnej wymaga od kontrolera po prostu bardziej krytycznej weryfikacji materiału dowodowego i - w przypadku ustalenia innej rzeczywistości - zgromadzenia na to stosownych kontrdowodów. Niemniej jednak i te ustalenia powinny być poparte materiałem dowodowym. W przeciwnym razie kontroler narazi się na zarzut nieodpowiedniego dokumentowania stanu faktycznego, na co zwraca uwagę orzecznictwo NIK (np. uchwała Kolegium NIK z dnia 26 października 2016 r., KPK-KPO.000.045.2016, 18) ${ }^{12}$.

Nazwę ,prawda materialna/obiektywna” można traktować po prostu jako synonim prawdy, tak jak proponuje Tomasz Gizbert-Studnicki w obszarze postępowania cywilnego $(2009,6-8)^{13}$. Zasada prawdy materialnej/obiektywnej wiąże się z obowiązkiem dążenia kontrolera do dokonania ustaleń faktycznych odpowiadających rzeczywistości ,w tej mierze, w jakiej jest to faktycznie i prawnie możliwe"14. Prawda formalna jest natomiast pojęciem zrelatywizowanym do pewnej procedury - konkretnie zaś do postępowania kontrolnego. Tomasz Gizbert-Studnicki wyciąga z tego wniosek, że o prawdziwości danego twierdzenia decyduje zgodność czynności sądu (w naszym przypadku instytucji kontrolującej) z regułami tej procedury (Gizbert-Studnicki 2009, 11).

Skierowany do kontrolera prawny nakaz ustalania stanu faktycznego nie wystarczy do osiągnięcia prawdy materialnej. Kontroler musi być dodatkowo wyposażony w odpowiednie narzędzia poznawcze. Te spostrzeżenie nie jest nowe, albowiem doktryna prawa od dawna dostrzega, że na zakres obowiązywania zasady prawdy materialnej mają wpływ „ograniczenia”, jakie ustawodawca stawia tej zasadzie (na przykład Elżbieta Jarzęcka-Siwik pisze o ,koszcie dotarcia do prawdy materialnej": Jarzęcka-Siwik, Berek, Skwarka, Wrona 2018, 157; Jarzęcka-Siwik, Skwarka 2012, 41; zob. też Kowalski 2017, 32). Innymi słowy, ustalenia kontroli mają ograniczoną możliwość odzwierciedlenia prawdy z powodu braku uprawnień do posługiwania się np. podsłuchem czy prowokacją.

${ }^{12}, \mathrm{Z}$ formalnoprawnego punktu widzenia, uzasadnieniem do usunięcia ustalenia z opisu stanu faktycznego mogłoby zatem być uznanie, że jest ono niezgodne ze stanem faktycznym, w szczególności że nie ma umocowania w materiale dowodowym zgromadzonym w toku kontroli”.

${ }^{13}$ Autor ten uważa, że przydawka „materialna” pełni funkcję konfirmującą, nie wyodrębnia jakiegoś szczególnego rodzaju prawdy.

${ }^{14}$ Przenosząc na grunt prawa o kontroli twierdzenie Tomasza Gizberta-Studnickiego odnoszące się do postępowania cywilnego (Gizbert-Studnicki 2009, 10). 


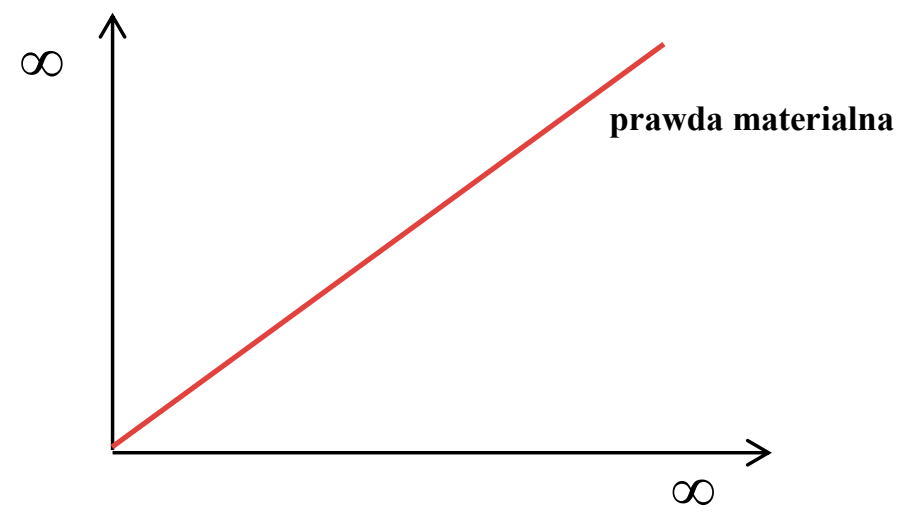

Wykres 1. Powiązanie prawdy materialnej z narzędziami poznawczymi oraz ze swobodą doboru tych narzędzi i oceny dowodów.

Linia czerwona wskazuje na stopień przyczyniania się do urzeczywistnienia prawdy materialnej. Znak „œ” oznacza brak ograniczeń.

\section{Źródło: opracowanie własne}

W postępowaniu kontrolerskim występują określone środki dowodowe (narzędzia poznawcze) oraz pewien zakres swobody w ich wyborze oraz w wyciąganiu wniosków z materiału dowodowego. Prawda materialna może zostać maksymalnie urzeczywistniona w warunkach zapewnienia wszelkich możliwych narzędzi poznawczych oraz pełnej swobody ich doboru i oceniania dowodów. Jakiekolwiek ograniczenia stanowią balast ciążący w kierunku prawdy formalnej, rozumianej jako twierdzenia o rzeczywistości formułowane według reguł proceduralnych. Jak pamiętamy, prawda formalna nie oznacza ex definitione kłamstwa. Im większe ograniczenie narzędzi poznawczych i usztywnienie ich doboru oraz oceny dowodów, tym większe prawdopodobieństwo rozchodzenia się z prawdą.

Co oczywiste, nie da się osiągnąć idealnych warunków urzeczywistnienia prawdy materialnej, aczkolwiek interesujące mogłoby być przedstawienie na wykresie 1 umiejscowienia względem siebie instytucji systemu kontroli (w tym zwłaszcza NIK). Jest to niestety karkołomne zadanie ze względu na zróżnicowanie kompetencyjne podmiotów kontrolujących i wynikające $\mathrm{z}$ tego trudności porównawcze. Problematyczne okazuje się nawet konkluzywne przeanalizowanie kryteriów kontroli, którymi dysponują. Jak pamiętamy, zasada prawdy materialnej zobowiązuje do badania danego zjawiska w związku przyczynowo-skutkowym z innymi faktami. Jedną z płaszczyzn badań (tj. poznania faktów) wyznaczają kryteria kontroli, które zaliczam do narzędzi poznania prawdy. Prawda materialna wymaga uwzględniania wszystkich okoliczności towarzyszące badanym zjawiskom (Kałużny 2016, 128), a więc stosowania całego spektrum kryteriów 
kontroli (co wynika z zasady kompleksowości) ${ }^{15}$. I oto na przykład regionalne izby obrachunkowe (RIO) mogą stosować kryterium celowości względem gospodarki finansowej jednostek samorządu terytorialnego w zakresie zadań administracji rządowej (art. 5 ust. 2 ustawy z dnia 7 października 1992 r. o regionalnych izbach obrachunkowych, Dz.U. z 2016 r., poz. 561 ze zm.), podczas gdy NIK takiego uprawnienia nie posiada. Musielibyśmy wobec tego skonstatować, że NIK może tą prawdę ustalić w bardziej ograniczonym stopniu, aniżeli RIO. Powiedzielibyśmy, że to przyzwolenie prawodawcy, aby RIO ustalała rzeczywistość w szerszej wiązce związków przyczynowo-skutkowych. Z kolei ograniczenia NIK zwiększają ryzyko sformułowania niepoprawnych wniosków, choć bynajmniej nie muszą przesądzać o dokonaniu nieprawdziwych ustaleń, o czym będzie jeszcze mowa. W każdym razie okoliczność ta utrudnia porównanie NIK i RIO, albowiem ta pierwsza cieszy się generalnie szerszą przedmiotową zdolnością kontrolnoprawną ${ }^{16}$.

\section{USTALENIA KONTROLERSKIE - POZNAWANIE PRAWDY}

Do kanonów filozofii należy wielowiekowe stwierdzenie, że prawda jest zgodnością rzeczy i myśli (veritas est adaequatio rei et intellectus). Zachowuje ono wciąż aktualność: współczesna jurysprudencja pojmuje prawdę materialną jako uniwersalną dyrektywę proceduralną nakazującą wydawanie orzeczeń na podstawie obiektywnego stanu faktycznego (Łukowski, Żukowski 2014, 49), zaś na przykład Podręcznik Kontrolera NIK wywodzi z niej powinność odzwierciedlania przez ustalenia kontrolne rzeczywistego stanu rzeczy, jako że ,ustalenia faktyczne powinny stanowić podstawę wszelkich rozstrzygnięć" (Podręcznik kontrolera Najwyższej Izby Kontroli 2002, A.1. 6, B.1 8) ${ }^{17}$. Analogia jest więc oczywista. Bądź co bądź, istota materialnie pojętej prawdziwości polega na zgodności orzeczenia (sądu) z rzeczywiście zaistniałym stanem rzeczy, tj. z obiektywną, pozajęzykową rzeczywistością (Łukowski, Żukowski 2014, 49).

Obiekt, do którego odnoszą się ustalenia bywa wielorako określany: rzeczywistość (Jarzęcka-Siwik, Berek, Skwarka, Wrona 2018, 156), stan rzeczywisty (Jarzęcka-Siwik, Skwarka 2011, 98), rzeczywisty stan rzeczy (Podręcznik kontrolera Najwyższej Izby Kontroli 2002, B.1, 8; Jarzęcka-Siwik, Skwarka 2011,

${ }^{15}$ Nakazuje ona dokonywanie ustaleń pod kątem widzenia wszystkich możliwych kryteriów kontroli. Kontrolujący ma dokonywać ustaleń „,W powiązaniu ze wszystkimi innymi faktami i okolicznościami towarzyszącymi, mającymi znaczenie dla obiektywnego spojrzenia na dane zagadnienie" (Kałużny 2016, 129). Czesław Nawłoka-Bielecki uważał, że zasada kompleksowości pełni w stosunku do zasady prawdy materialnej rolę ,służebną” (1991, 8-9).

${ }^{16}$ Zdolność kontrolnoprawna to prawna możliwości nawiązywania, kształtowania oraz wygaszania przez NIK stosunku kontrolnoprawnego z podmiotem kontrolowanym.

${ }^{17}$ Podręcznik posługuje się terminem ,zasada prawdy obiektywnej”. 
98), rzeczywisty charakter $i$ stan zjawisk (Padrak 2003, 35), prawda (Jarzęcka-Siwik, Skwarka 201, 98; Kałużny 2016, 128), prawda obiektywna (Robaczyński 2003, 32), fakt (Podręcznik kontrolera Najwyższej Izby Kontroli 2002, B.1, 8), stan faktyczny (Padrak 2003, 35). Podobnie różnorodnie nazywana jest pożądana relacja pomiędzy ustaleniami a obiektem: odzwierciedlenie (Podręcznik kontrolera Najwyższej Izby Kontroli 2002, B.1, 8; Jarzęcka-Siwik, Skwarka 2011, 98), zgodność (Jarzęcka-Siwik, Berek, Skwarka, Wrona 2018, 156; Padrak 2012, 60; Kałużny 2016, 128), petna zgodność (Padrak 2012, 60), odpowiadanie (Kałużny 2016, 128). Generalnie można powiedzieć, że zasada prawdy materialnej odnosi się do relacji pomiędzy dwoma przedmiotami: ustaleniem [U] oraz rzeczywistościa [R]. Zasada ta wyznacza idealną relację pomiędzy nimi, polegającą na zachodzeniu pełnej zgodności (odpowiedniości) między ustaleniem a rzeczywistością: $\mathrm{U}(\mathrm{R})$.

Samo ustalenie kontrolerskie składa się z dwóch zasadniczych elementów: a) odkrycia (poznania) rzeczywistości oraz b) sformułowania na podstawie tego odkrycia wypowiedzi opisującej rzeczywistość.

Odkrycie rzeczywistości polega na uświadomieniu sobie prawdy o kontrolowanej działalności, uzmysłowieniu sobie tego, jak było. Poznawanie rzeczywistości następuje $\mathrm{w}$ drodze analizy informacji docierających do obserwatora (kontrolera). Każdemu aktowi poznania rzeczywistości musi jednak towarzyszyć krytyczna analiza informacji. Chodzi o uwzględnienie czynników, które mogą doprowadzić do mylnego ustalenia prawdy, tj. wyciągnięcia niewłaściwych wniosków z docierających bodźców. Mylące mogą być nawet oczywiste obserwacje. Na przykład typowym sposobem poznania liczby krzeseł w pomieszczeniu jest weryfikacja wzrokowa. Fakt, że obserwator widzi 15 krzeseł wcale nie przesądza, że w pomieszczeniu znajduje się taka akurat ich liczba. Należy uwzględnić czynniki wprowadzające w błąd, na przykład wiszące lustro, które daje złudzenie innej liczby krzeseł, aniżeli jest ich w rzeczywistości. Weryfikowanie czynników potencjalnie mylących co do prawdy wiąże się z pracochłonnością. Im mniej czasu przeznacza się na odkrycie prawdy, tym większe ryzyko pomyłki. Wiele zależy także od tzw. doświadczenia życiowego kontrolera oraz posiadanej przez niego wiedzy ogólnej na dany temat, którą coraz łatwiej zdobyć wraz z rozwojem technologii informatycznych ${ }^{18}$.

W literaturze o kontroli do opisu poszukiwania prawdy przez kontrolę niekiedy używa się słowa „obraz”. Na przykład Jacek Jagielski omawiając kategorie rozumienia kontroli stwierdził, że oznacza ona funkcję obejmującą m.in. „ustalanie rzeczywistego obrazu”, tj. obserwowanie i rozpoznawanie danej działalności lub stanu (Jagielski 2007, 15). Z kolei Jarosław Szymanek napisał, że kontrola prowadzi do uformowania „obrazu działania jednostki

${ }^{18}$ Zob. np. artykuł o sceptycyzmie zawodowym w audycie (Ciołek 2017, 33-39). 
kontrolowanej" (Szymanek 2006, 21). Uważam, że obraz to produkt końcowy wcześniejszego poznawania rzeczywistości. Obraz komunikuje przeświadczenia kontrolującego o tym, jak się rzeczy mają; nie jest zaś tą rzeczywistością. Miarą „rzeczywistości obrazu” będzie stopień zgodności pomiędzy tym, jakie informacje uznaje odbiorca obrazu za prawdziwe a rzeczywistością. Kontrola posiada immanentną zdolność do kształtowania obrazu podmiotu kontrolowanego. Nie sądzę przy tym, aby było możliwe uzyskanie takiego obrazu, który u wszystkich wywoła przeświadczenia absolutnie korespondujące z rzeczywistością. Pewna „kreatywność” obrazu jest nieunikniona, albowiem obraz to przedstawienie czegoś przez kogoś, a więc ma w mniejszym lub większym stopniu charakter subiektywny ${ }^{19}$.

\section{PRAWDA KONTROLERSKA}

Bezpośrednim celem poznania prawdy w postępowaniu kontrolnym jest jej przedstawienie (zakomunikowanie) w postaci opisu. W przypadku NIK i innych instytucji systemu kontroli prawodawca przewiduje językowy obraz stanu faktycznego w postaci ciągu wypowiedzi zawartych w sformalizowanym dokumencie nazwanym „wystąpienie pokontrolne”. Wypowiedzi mają zadanie opisywać kontrolowany wycinek rzeczywistości. Są to zdania w sensie logicznym, a więc prawdziwe albo fałszywe względem opisywanej przez nie rzeczywistości ${ }^{20}$.

Zagadnienie prawdziwości zdań opisujących stan faktyczny i prawdy kontrolerskiej jest złożone i w tym miejscu poruszę jedynie kilka jego aspektów. Wyobraźmy sobie kontrolę koordynowaną w pięciu szkołach (A, B, C, D, E), do których trafia jednocześnie pięciu różnych kontrolerów i którzy mają do czynienia z takim samym stanem faktycznym i prawnym. Ich zadaniem jest udzielenie odpowiedzi na pytanie zawarte w programie kontroli „Ile krzeseł znajdowało się w pomieszczeniu?", a które to pytanie zostało ukierunkowane na wyznacznik w postaci przepisu ustawowego w brzmieniu: „W pomieszczeniu powinno znajdować się przynajmniej 15 krzesel".

1) Kontroler w szkole A zawarł w wystąpieniu pokontrolnym ustalenie o treści „W pomieszczeniu znajdowało się 20 krzeseł”21. Dyrektor szkoły nie złożył zastrzeżeń do tego ustalenia.

${ }^{19} \mathrm{Na}$ potrzeby artykułu opis będę utożsamiał z ustaleniem.

20 „Każda wypowiedź oznajmująca, dająca sprawozdanie z pewnego stanu rzeczy, informująca, że tak jest albo tak nie jest nazywana jest zdaniem w sensie logicznym". Zdanie jest prawdziwe, jeśli opisuje sytuację, która zachodzi w rzeczywistości pozajęzykowej, zaś zdanie jest fałszywe, jeśli opisuje sytuację, która nie zachodzi w rzeczywistości pozajęzykowej.

${ }^{21}$ Zakładam, że ustalenie zostało udowodnione stosownymi oględzinami, również w przypadku pozostałych szkół, tj. B-E. 
2) Kontroler w szkole B zawarł w wystąpieniu pokontrolnym ustalenie o treści „W pomieszczeniu znajdowało się 18 krzeseł”. Kontroler nie uwzględnił bowiem dwóch krzeseł, którym brakowało po jednej nodze. Dyrektor szkoły nie złożył zastrzeżeń do tego ustalenia.

3) Kontroler w szkole $\mathrm{C}$ zawarł w wystąpieniu pokontrolnym ustalenie o treści „W pomieszczeniu znajdowało się 14 krzeseł”. Kontroler nie uwzględnił bowiem dwóch krzeseł, które nie posiadały jednej z nóg. Ponadto nie uwzględnił również czterech krzeseł składanych. Dyrektor szkoły nie złożył zastrzeżeń do tego ustalenia.

4) Kontroler w szkole D zawarł w wystąpieniu pokontrolnym ustalenie o treści „W pomieszczeniu znajdowało się 14 krzeseł” z powodów analogicznych do kontrolera ze szkoły C. Dyrektor szkoły D złożył zastrzeżenia do części tego ustalenia twierdząc, że krzesła składane powinny być wliczane do ogólnej liczby krzeseł, ponieważ mogą być szybko przygotowane do używania. Zespół Orzekający uwzględnił zastrzeżenie i podniósł liczbę krzeseł w pomieszczeniu do $\mathbf{1 8 .}$

5) Kontroler ze szkoły E zawarł w wystąpieniu pokontrolnym ustalenie o treści „W pomieszczeniu znajdowało się 14 krzeseł” z powodów analogicznych do kontrolerów ze szkół C i D. Dyrektor szkoły E złożył zastrzeżenia do ustalenia twierdząc, że krzesła składane powinny być wliczane do ogólnej liczby krzeseł, ponieważ mogą być szybko przygotowane do używania. Ponadto podniósł, że uwzględnić należy także dwa krzesła $\mathrm{z}$ brakującymi nogami. Zespół Orzekający uwzględnił zastrzeżenie w części - w celu zachowania jednolitości z poprzednim rozstrzygnięciem - uwzględnił cztery krzesła składane oraz jedno z krzeseł bez nogi, ponieważ noga poddawała się łatwemu samodzielnemu montażowi i krzesło mogło być - w tym samym czasie co krzesła składane - przygotowane do używania ${ }^{22}$. Ustalona liczba krzeseł wyniosła w tym przypadku 19.

Jak widzimy, problem opisu stanu faktycznego występuje na płaszczyźnie normatywno-semantycznej. Oto w identycznym stanie faktycznym mamy cztery różniące się od siebie ustalenia. Udzielenie odpowiedzi na pytanie, które z nich jest ,prawdziwe”, zależy od zdefiniowania desygnatu badanego obiektu i to w kontekście normatywnym (tj. woli prawodawcy) ${ }^{23}$.

Ustalenia kontroli formułowane są w postaci zdań będących rezultatem poznawania według reguł proceduralnych i pretendują do odzwierciedlania prawdy. Jak wszystkie wypowiedzi o rzeczywistości, tworzą własną rzeczywistość (rzeczywistość językową). Analogicznie do Tadeusza Widły i Doroty Zienkiewicz, którzy w odniesieniu do zdań sformułowanych na podstawie sądowych reguł proceduralnych posługują się pojęciem ,prawda sądowa” (Widła,

${ }^{22}$ Nie uwzględnił natomiast drugiego krzesła $\mathrm{z}$ brakującą nogą, $\mathrm{z}$ powodu jej mechanicznego uszkodzenia. Przykład krzeseł może być dalej modyfikowany o takie warianty, jak na przykład krzesła obrotowe czy siedziska.

${ }^{23}$ Kontrolujący dokonuje ustalenia intencji prawodawcy. 
Zienkiewicz 2005, 93-942) ${ }^{24}$, moglibyśmy powiedzieć o „prawdzie kontrolerskiej”, jako o rzeczywistości wyłaniającej się z ustaleń poczynionych w drodze postępowania kontrolnego. Aby to ukazać powróćmy do przykładu krzeseł. Oto w pięciu ww. wystąpieniach pokontrolnych, stanowiących oficjalne stanowisko instytucji kontrolującej, mamy cztery różniące się od siebie ustalenia. Jako zamieszczone w odrębnych dokumentach, odmienności te mogą być trudne do wychwycenia przez czytelnika. Problem nabrzmiewa natomiast podczas przygotowywania informacji zbiorczej o wynikach tych kontroli. Na przykład sformułowanie w niej podsumowania, że „spośród pięciu skontrolowanych szkół, jedna nie miała wymaganej prawem liczby krzeseł (15), albowiem w pomieszczeniu znajdowało się ich 14" byłoby zgodne z prawdą kontrolerską lecz niezgodne $\mathrm{z}$ być może znaną już na tym etapie prawdą materialną. Trudno nawet napisać o liczbie krzeseł według jednolitego rozumienia organu kontrolującego, ponieważ w obiegu prawnym jest ich kilka i są sobie równoważne. Pewnym rozwiązaniem może być odwołanie się do szczegółowego opisu, na przykład: „w pięciu skontrolowanych szkołach znajdowało się 16 krzeseł tradycyjnych, w tym dwa krzesła z brakującą nogą, a także cztery krzesła składane". Nie zawsze jest to jednak możliwe, na przykład ze względu na brak danych (kontroler ze szkoły A mógł nie uwzględnić owego rozróżnienia w materiale dowodowym, a na dokonanie ustalenia jest już za późno). Z drugiej strony, pominięcie w ogóle informacji o krzesłach byłoby formą nieprawdy, polegającą na wybiórczym przedstawianiu ustaleń.

Dużą część rzeczywistości odbieramy intuicyjnie i nie da się z góry przewidzieć wszystkich ewentualnych rozbieżności obserwatorów w projektowaniu obrazu stanu faktycznego. Jeżeli jednak nie dojdzie w miarę wcześnie do skoordynowania definicji, wówczas powstanie realne zagrożenie, że do obrotu prawnego wprowadzone zostaną niezgodne ze sobą ustalenia. W przypadku NIK obowiązek zapewnienia spójności spoczywa na koordynatorze kontroli, to bez przekazania mu w porę sygnału o zaistnieniu problemu interpretacyjnego, nie wypełni skutecznie swojego zadania. Zagrożenie jest realne zwłaszcza wtedy, gdy każdy z kontrolerów uważa swoje rozumienie rzeczywistości (tu „krzesła” lub opisanego dalej „długopisu”) za oczywiste. Sytuację może pogarszać też ewentualny pośpiech kontrolerów wynikający z nadmiernej liczby zaplanowanych ustaleń w stosunku do przeznaczonych na kontrolę zasobów (zwłaszcza czasu).

Również na kontrolerach opracowujących informacje o wynikach kontroli ciąży obowiązek dążenia do prawdy materialnej. Manifestuje się on m.in. powinnością krytycznej analizy pozyskanych w trakcie kontroli danych obrazujących rzeczywistość i doprowadzenia ich do „odpowiedniości”. Za naruszenie zasady

${ }^{24}$ Tadeusz Widła i Dorota Zienkiewicz twierdzą, że prawda sądowa to zbiór zdań będących rezultatem poznawania według reguł proceduralnych. Zob. także uwagi dotyczące prawdy sądowej Tomasza Gizberta-Studnickiego (Gizbert-Studnicki 2009, 5-19). 
prawdy materialnej należałoby uznać na przykład dokonywanie analiz porównawczych zjawisk, których metodologia opisu znacznie się różni. Rozdźwięk między prawdą kontrolerską a materialną stawia niekiedy kontrolerów w dylematach etycznych, a w skrajnych przypadkach może narazić na zarzut poświadczenia nieprawdy.

\section{PRAWDA MATERIALNA A MOMENT ASERCJI}

Poznaniu towarzyszy nabywanie przekonania o tym, co miało miejsce, a co się nie wydarzyło, co istniało, a co nie istniało. Przekonaniem nazwiemy uświadomienie sobie docierających informacji i wyciągnięcie z nich wniosków uwzględniających ryzyko mylnego poznania rzeczywistości. Ma ono charakter stopniowalny i tylko w części przypadków obserwator może nabyć najwyższe przekonanie (pewność $=1$ ) o poznaniu danego fragmentu rzeczywistości ${ }^{25}$. Naprowadza nas to na psychologiczny element zdań opisujących rzeczywistość, którym jest tzw. moment asercji (przekonania) o prawdziwości tych zdań.

Zasada prawdy materialnej wymaga, aby dążyć do dokonywania ustaleń, co do których wypowiadający się nabył przekonanie, że odzwierciedlają rzeczywistość. Ustaleniom powinien towarzyszyć możliwie najwyższy „moment asercji” ${ }^{\prime 26}$, lecz niekoniecznie wymagana jest absolutna pewność $(=1)$. W praktyce kontrolerskiej często pozostaje zadowolić się osiągnięciem poziomu przekonania o poznaniu prawdy, który jest niższy od pewności $(<1)$. Na przykład podczas standardowej kontroli poprawności dokumentacji nie weryfikuje się z udziałem grafologa autentyczności złożonych na niej podpisów. Takie badanie byłoby zasadne, gdyby kontroler nabrał podejrzenia oszustwa. Jest to jednak rzadkie, zapewne rzadsze od skali oszukiwania.

Stopień pewności uzależniony jest od stopnia wiarygodności dowodu oraz jego przydatności w ustaleniu stanu faktycznego. Na to również w znacznym stopniu wpływa płaszczyzna normatywno-semantyczna. Aby to ukazać, proponuję następujący eksperyment myślowy: wyobraźmy sobie pewną kontrolę, która ukierunkowana została na stwierdzenie, czy spełniono wymóg ustawy, aby w zasobach kontrolowanego znajdowała się określona liczba „długopisów”. Stan rzeczywisty przedstawia zdjęcie 1 .

${ }^{25}$ Piotr Łukowski stosuje następujące oznaczenie momentu asercji („m.a”): przekonanie, że tak jest (m.a. $=1)$, przypuszczenie $(0,5 \leq \mathrm{m} . \mathrm{a} .<1)$, wątpienie $(0<\mathrm{m} . \mathrm{a} .<5)$, przekonanie, że tak nie jest (m.a.=0); zob. Łukowski (2012, 132-133).

${ }^{26} \mathrm{Im}$ silniejsze jest przekonanie o prawdziwości sądu, tym silniejszy jest moment jego asercji. 


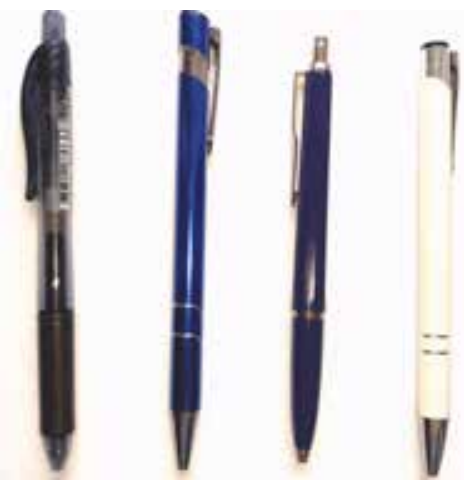

Zdjęcie 1. Prawda materialna a prawda kontrolerska względem liczby długopisów. [Opis w tekście].

Źródło: opracowanie własne

Dokonanie ustalenia zależy od przyjętej definicji „długopisu” oraz nakładu pracy włożonego w poznanie stanu rzeczywistego. Oto kontroler X stwierdza w wyniku prostej obserwacji, że na stole znajdują się 4 długopisy. Kontroler Y uważa, że dodatkowo należy sprawdzić, ile z nich posiada wkład, a kontroler $\mathrm{Z}$ dąży do weryfikacji, ile z tych wkładów jest piszących ${ }^{27}$. Zakładając, że zdjęcie $\mathrm{nr} 1$ jest wiarygodne (np. pochodzi z oględzin dokonanych $\mathrm{w}$ trakcie kontroli) ${ }^{28}$, na jego podstawie stan faktyczny może ustalić jedynie kontroler X. Dla pozostałych będzie to dowód wiarygodny lecz niewystarczający do ustalenia liczby długopisów. Zdjęcie to (jako dowód) czyni zadość zasadzie prawdy materialnej względem definicji „długopisu” przyjętej przez kontrolera X, a zarazem jej nie zaspokaja w odniesieniu do definicji pozostałych kontrolerów. Bez uzyskania dodatkowego dowodu kontrolerzy Y i Z mogliby jedynie wyrazić przekonanie, że: „być może kontrolowany posiada w swoich zasobach 4 długopisy". Niekiedy moment asercji daje się podnieść za pomocą zabiegu opisania skali niepewności jako swoistego faktu, na przykład w postaci stwierdzenia: „kontrolowany posiada w swoich zasobach co najwyżej 4 długopisy”. Zdanie to demonstruje pewność kontrolującego, że długopisów jest nie więcej niż 4, a zarazem niepewność co do ich konkretnej liczby. Komunikuje więc prawde przybliżona, w jakimś stopniu nieznaną. Zawężono bowiem zbiór wszystkich możliwych stanów faktycznych. Czasami ustalenie takie będzie wystarczające - jeżeli na przykład ustawa wymaga, że długopisów powinno być co najmniej 5, wówczas tenże przybliżony opis stanu faktycznego pozwoli na stwierdzenie naruszenia prawa. W praktyce kontrolerskiej zdarza się

${ }^{27}$ Przykład ten może być jeszcze bardziej skomplikowany, jeśli dany długopis pisze przerywając.

${ }^{28}$ Oraz że przedstawia wszystkie przedmioty służące do pisania znajdujące się w zasobach kontrolowanego. 
- choć rzadko - komunikować expressis verbis prawdę przybliżoną. Oto w jednym z wystąpień pokontrolnych NIK stwierdziła nieprawidłowość polegającą na niezłożeniu do sądu wniosków o ujawnienie prawa własności do „około” 500 działek (wystąpienie pokontrolne Departamentu Administracji Publicznej NIK z 23 grudnia 2013 r., KAP-4101-02-04/2013, s. 4). Pomimo nieustalenia konkretnej liczby działek, Izba zdecydowała się na sformułowanie nieprawidłowości w relacji do niepewnej rzeczywistości (w znaczeniu niepewności co do skali). Uważam to za właściwe podejście. Podmiot kontrolujący (np. NIK) nie musi być gwarantem absolutnej pewności stwierdzonego stanu faktycznego. Wystarczy jednak, że będzie gwarantem określonego prawdopodobieństwa jego prawdziwości. Adresaci wystąpienia pokontrolnego mają jednak prawo wiedzieć, jakie jest przekonanie kontrolującego o prawdziwości opisanych faktów, zaś podmiot kontrolujący ma obowiązek taką informację rzetelnie przekazywać. W rzeczy samej, nieuczciwość w tym względzie byłaby formą naruszenia zasady prawdy materialnej, albowiem odnosi się ona w równym stopniu do ujawniania prawdy o prawdopodobieństwie korespondowania opisu z pozajęzykową rzeczywistością. Warto odnotować, że odzwierciedla to jedno z zaleceń INTOSAI, aby poziom ufności, który można zagwarantować przewidywanym użytkownikom, został określony i podany do wiadomości w przejrzysty sposób (Najwyższa Izba Kontroli 2016, 14). „Przewidywani użytkownicy” - napisano w standardach INTOSAI - „chcą być pewni, że informacje, z których będą korzystać przy podejmowaniu decyzji, są rzetelne i wiarygodne" (Najwyższa Izba Kontroli 2016, 14). Zmodyfikowałbym jednak to stwierdzenie, ponieważ jest niezgodne z inną (skądinąd słuszną) obserwacją INTOSAI, że ,z powodu nieodłącznych ograniczeń kontrola nigdy nie dostarcza absolutnego zapewnienia" (Najwyższa Izba Kontroli 2016, 14). Należałoby raczej stwierdzić, że adresaci chcą być pewni stopnia, w jakim informacje, z których będą korzystać przy podejmowaniu decyzji, są rzetelne i wiarygodne.

Można więc powiedzieć, że wszelkie kompromisy z prawdą materialną są dopuszczalne tylko wówczas, gdy jednocześnie towarzyszy im uczciwość (tj. zgodność z prawdą) w opisie tego kompromisu. A contrario, formułowanie wypowiedzi o rzeczywistości, które są w przekonaniu kontrolującego niepewne, i przedstawianie ich jako pewne, stanowi naruszenie zasady prawdy materialnej. Jednocześnie im więcej prawdy jest do odkrycia, tym z reguły mniejsza jest pewność poznania. Świadomość tego powinny mieć osoby przygotowujące założenia kontroli, zwłaszcza formułujące tematy i cele kontroli.

\section{ZASADY OGRANICZAJĄCE ZASADĘ PRAWDY MATERIALNEJ}

Zasadę prawdy materialnej ograniczają realia kontroli i inne zasady kontroli, takie jak zasada sprawności czy zasada minimalizowania dolegliwości kontrolnych. Ponadto urzeczywistnianie królowej zasad w sposób szczególny wyznacza 
zasada proporcjonalności (proporcji) ${ }^{29}$, którą rozumiem jako skierowany do kontrolerów nakaz poznawania prawdy przynajmniej do minimalnie akceptowalnego poziomu przekonania o stanie rzeczywistym. Poziom ten wyznacza optymalne wypośrodkowanie pomiędzy nakładami zasobów (kontrolującego i kontrolowanego), ryzykiem błędnego odkrycia rzeczywistości i wagą (ważnością) ustalenia ${ }^{30}$. Choć generalnie radzi się kontrolerom, aby stan faktyczny ustalać na podstawie dowodów zebranych w trakcie kontroli przy wykorzystaniu różnych metod badawczych, tak żeby kontrola „wykazała rzeczywistość” (Dobrowolski 2003, 128), to w pewnych sytuacjach poprzestanie w pozyskaniu wiedzy o rzeczywistości na jednej metodzie (na przykład na dokumencie) jest wystarczające. Ortodoksyjność w stosowaniu zasady dociekliwości (Sprawozdanie 2017, 3) może bowiem godzić w inną zasadę - minimalizowania dolegliwości kontrolnych ${ }^{31}$ i prowadzić do marnotrawienia zasobów kontrolerskich na potwierdzanie faktów, co do których prawdziwości nie ma wątpliwości, albo wątpliwości te są nieznaczne i nie mają dużego znaczenia dla istoty kontroli ${ }^{32}$.

Zasada proporcjonalności, a także inne zasady opozycyjne, sankcjonują nieuniknioność „kompromisów z prawdą”. Precyzyjnie rzecz ujmując, chodzi o „kompromis” w znaczeniu akceptacji określonej niepewności względem poznania prawdy, nie zaś akceptacji dla uznawania poznanej nieprawdy za prawdę (tego bezwzględnie zabrania zasada prawdy materialnej). Nawiasem mówiąc, z ograniczeniami poznawczymi godzi się nawet orzecznictwo NIK, albowiem dopuszcza formułowanie w wystąpieniu pokontrolnym stwierdzeń, co do których nie można jednoznacznie orzec, że są prawdziwe (uchwała Zespołu Orzekającego Komisji Rozstrzygającej NIK z 21 marca 2016 r., KPK-KPO.443.029.2016, 15) 33. Przykładem typowego akceptowalnego kompromisu jest wypowiadanie się o rzeczywistości na podstawie próby badawczej. Potrzeba doboru próby do kontroli występuje wszędzie tam, gdzie nie jest możliwe skontrolowanie wszystkich jednostek lub

${ }^{29} \mathrm{O}$ istnieniu tej zasady nadmieniają co najmniej dwa opracowania (Stępiński 1969, 54; Sztajerwald, 1969, 15-26).

${ }^{30}$ Zagadnieniem wartym osobnego opracowania jest moment asercji przy stwierdzaniu nieprawidłowości.

${ }^{31}$ Zasada minimalizowania dolegliwości kontrolnych została przywołana przez Marzenę Antoniak $(2012,111)$.

${ }^{32} \mathrm{Na}$ przykład ustalenie wielkości gotówki zamkniętej w kasie pancernej polega na jej przeliczeniu. Nie daje to jednak absolutnej pewności co do stanu kasy, albowiem banknoty mogą być fałszywe - a takiego rozstrzygnięcia może dokonać jedynie wyspecjalizowany do tego podmiot.

${ }^{33}$ „Zespół Orzekający na obecnym etapie postępowania nie jest w stanie jednoznacznie stwierdzić, czy prawdziwy jest zapis zawarty w wystąpieniu pokontrolnym i na ile wyjaśnienie przedstawione w zastrzeżeniach odnosi się do zakwestionowanego stwierdzenia. Mając jednak na uwadze, że zakwestionowany fragment jest wyłącznie elementem opisu stanu faktycznego i nie wiążą się z nim żadne uwagi lub nieprawidłowości, Zespół postanowił o pozostawieniu go w wystąpieniu pokontrolnym po uzupełnieniu (w przypisie) o treść wyjaśnień (...) zamieszczonych w zastrzeżeniach". 
wszystkich operacji dotyczących przedmiotu kontroli (Podręcznik 2002, B.5, 5). Z punktu widzenia urzeczywistnienia prawdy materialnej najbardziej pożądane są próby reprezentatywne, albowiem pozwalają uogólnić wyniki na całą populację, z której zostały pobrane.

\section{PRAWDA KONTROLERSKA A PRAWDA NIEPELNA}

Jak wiemy, zgodność pomiędzy rzeczywistością a jej opisem ma miejsce wtedy, gdy wszystkie zdania opisujące korespondują z faktami. Jednak do ukazania prawdy sama zgodność opisu to za mało. Równie ważna jest kwestia zupełności wypowiedzi o faktach. Oto wybiórczość opisywania rzeczywistości może się niekiedy przerodzić w kłamstwo o pozorach prawdy (gdyby na przykład powiedzieć - zgodnie z rzeczywistością - że wszyscy są chorzy, lecz nie dodać, że jedni mają katar, a inni gruźlicę). Na tej właśnie płaszczyźnie istnieje według mnie możliwość dokonania rozróżnienia pomiędzy prawdą materialną a obiektywną: o ile zasada prawdy materialnej domaga się, aby wszystkie wypowiedzi opisujące stan faktyczny były z tym stanem zgodne, o tyle zasada prawdy obiektywnej domaga się przedstawiania pełnego opisu danego fragmentu rzeczywistości. Idealną postacią urzeczywistnienia zasady prawdy obiektywnej jest opis całej rzeczywistości ${ }^{34}$ objętej badaniem:

$$
\begin{aligned}
& R=R_{1} \cup R_{2} \cup R_{3} \cup \ldots \cup R_{n} \\
& U(R) \supseteq U\left(R_{1}\right) \cup U\left(R_{2}\right) \cup U\left(R_{3}\right) \cup \ldots \cup U\left(R_{n}\right)
\end{aligned}
$$

Osiągnięcie zupełności jest w praktyce niemożliwe lub bardzo trudne. Opisy rzeczywistości muszą być zwięzłe, czego zresztą wyraźnie oczekuje ustawodawca (por. art. 53 ust. 1 pkt 4 ustawy o NIK). Gdyby bowiem ortodoksyjnie trzymać się nakazu zupełności, wówczas wiele wypowiedzi straciłoby walor komunikatywności. Segregowanie informacji staje się więc koniecznością, tym niemniej powinno być dokonywane poprawnie. Podręcznik Kontrolera wymaga od kontrolerów „uczciwości w prezentowaniu ustaleń" ${ }^{35}$, co wiąże się - jak sądzę - z problematyką istotności. Poznawany fragment rzeczywistości zazwyczaj składa się ze znacznej liczby „faktów składowych”. Po ich poznaniu kontroler ustala ich istotność (wagę) z punktu widzenia uczciwości opisu ${ }^{36}$. Następnie decyduje o progu istotności, a więc o tym, jaka waga będzie kwalifikowała poznane fakty do opisania

${ }^{34}$ Przez „całą rzeczywistość” rozumiem kontrolowany wycinek działalności jednostki. Dziękuję Mariuszowi Blankowi za konsultację matematycznego przedstawienia relacji pomiędzy ustaleniem a rzeczywistością.

${ }^{35}$ Obiektywizm definiowany jest m.in. jako uczciwe prezentowanie ustaleń kontroli: zob. Podręcznik kontrolera Najwyższej Izby Kontroli (2002, B.1, 8).

${ }^{36}$ Niekiedy jednak dogłębne poznanie wszystkich faktów nie jest konieczne, zwłaszcza w przypadku badania na próbie. 
W wystąpieniu pokontrolnym, a jaka do pominięcia (nazywam to „pierwszym ważeniem") ${ }^{37}$. Niezachowanie w tym konsekwencji naraża kontrolera na podejrzenie wybiórczego opisu rzeczywistości, a nawet manipulacji. Uczciwym wyjściem jest informowanie czytelnika o fragmentaryczności opisu. Przykładem takiego właśnie podejścia jest używanie zwrotów: „w szczególności”, „w tym” czy „między innymi". Tym ostatnim wyrażeniem NIK posługuje się średnio 14 razy w każdym wystąpieniu pokontrolnym ${ }^{38}$.

Niepełność opisu nie przesądza o zafałszowaniu kontrolowanego stanu faktycznego i nie deprecjonuje prawdy kontrolerskiej jako takiej. Nawet niepełny opis prawdy pretenduje do poprawnego, jeżeli uwzględnia wszystkie fakty relewantne dla kontrolowanego fragmentu rzeczywistości. Dopiero manipulowanie obrazem rzeczywistości przejawiające się na przykład niekonsekwencją w formułowaniu opisu istotnych faktów w taki sposób, aby odbiorca uzyskał mylny obraz prawdy, stanowi działanie niedopuszczalne. Innym źródłem ograniczenia poznania i ujawniania prawdy są przepisy prawa zabraniające instytucjom kontrolującym dostępu do określonych informacji czy też ich rozpowszechnianie.

\section{PRAWDA MATERIALNA A ROZUMOWANIE}

$\mathrm{Na}$ opis stanu faktycznego składają się nie tylko proste stwierdzenia o rzeczywistości, lecz także wypowiedzi powstałe w wyniku rozumowania, tj. procesu myślowego polegającego na uznaniu za prawdziwe danego przekonania lub zdania na mocy innego przekonania lub zdania uznanego uprzednio za prawdziwe. Rozumowanie jest wielowątkowym zagadnieniem, a w tym miejscu poruszę tylko niektóre aspekty ${ }^{39}$.

Obok zakresu przedmiotowego kontroli, istotnym czynnikiem wyznaczającym to, ile faktów należy ustalić, jest okres objęty kontrolą. Obraz rzeczywistości, który dostarcza typowa kontrola, nie przypomina fotografii (tj. odzwierciedlenia faktów w konkretnym momencie), lecz zbliżony jest do projekcji filmowej (tj. odzwierciedlenia faktów w układzie dynamicznym) $)^{40}$. W kontroli o ograni-

${ }^{37} \mathrm{~W}$ odróżnieniu od „drugiego ważenia”, które odnosi się do stwierdzonych prawidłowości oraz nieprawidłowości i służy sformułowaniu oceny skontrolowanej działalności.

${ }^{38}$ Próbą objąłem 160 wystąpień pokontrolnych z lat 2017-2018 bez wystąpień dotyczących kontroli wykonania budżetu państwa.

${ }^{39}$ Przede wszystkim nie odnoszę się do sofizmatów, tj. rozumowań błędnych, takich jak błąd przypadkowości, sofizmat indukcji, błąd niewłaściwej przyczyny, opisanych np. w: Widła, Zienkiewicz (2005, 317 i n.).

${ }^{40}$ Piotr Łukowski zauważa, że wszystkie wypowiadane przez nas zdania, które orzekają o rzeczywistości, są zdaniami wyrażającymi pewien jej obraz. Na ten obraz wpływ mają postrzeganie przyczynowo-skutkowe świata materialnego; język, którym mówimy o świecie; logika, którą stosujemy formułując myśli i rozumując; pojęcia nadające strukturę siatce czasoprzestrzennej; obowiązujące prawo i obyczaj (Łukowski 2012, 136). 
czonych zasobach zakres przedmiotowy i okres objęty kontrolą są skorelowane: rozszerzaniu pierwszego towarzyszy skracanie drugiego, lub odwrotnie. Jednym ze znanych sposobów kompresji opisu rzeczywistości jest ogniskowanie wypowiedzi na zmianach w niej zachodzących.

Częstą metodą prezentacji ustaleń stanu faktycznego jest synteza, tj. tworzenie bardziej złożonego konstruktu z prostszych elementów. Oto można liczbę krzeseł przedstawić w postaci zestawienia faktów: „Szkoła posiadała 14 krzeseł w roku 2015, 16 w roku 2016, 11 w roku 2017, 28 w roku 2018", albo w postaci metaopisu: „W latach 2015-2018 liczba krzeseł w Szkole wzrosła o 100\%”. Prawdziwość drugiego stwierdzenia zależy od: a) prawdziwości ustalenia liczby krzeseł w latach 2015 i w 2018 oraz od: b) prawdziwości przyjętego rozumowania (tu: operacji obliczenia wartości procentowej zmiany). Zauważmy, że „wzrost o 100\%” jest również opisem stanu faktycznego, tym razem polegającym na opisie zajścia pewnej zmiany w poznanej rzeczywistości.

Do zalet tego rodzaju stwierdzeń należy możliwość ukazania istotnych z punktu widzenia kontroli zjawisk bez konieczności detalicznego wypowiadania się o całej złożonej rzeczywistości. W podanym przykładzie opis stanu faktycznego został ograniczony, ponieważ nie podano informacji o konkretnej liczbie krzeseł. Redukcje często wystarczają do ukazania istoty kontrolowanej rzeczywistości. Wyobraźmy sobie, że zadaniem kontrolera jest ustalenie relacji pomiędzy zmianą liczby krzeseł a zmianą liczby korzystających z nich uczniów. Wówczas opis stanu faktycznego mógłby brzmieć: „Pomiędzy 2015 a 2018 r. liczba krzeseł wzrosła o $100 \%$, podczas gdy liczba korzystających z nich uczniów wzrosła pomiędzy tymi latami o 20\%”. Oczywiście, do tak sformułowanego opisu stanu faktycznego można mieć wiele uwag jak choćby, że nie informuje o znaczącym spadku liczby krzeseł w 2017 r., lub że nie podaje, na który dzień danego roku te dane są aktualne. Niekoniecznie musi to być wadą. Jak słusznie zauważył Piotr Łukowski, „niewyobrażalna złożoność rzeczywistości oraz różnorodność i dynamiczność zjawisk w niej zachodzących sprawiają, że siła wyrazu naszego języka tkwi właśnie w braku precyzji, w wypowiedziach z konieczności niedookreślonych. Problem w tym, aby tego koniecznego z natury rzeczy braku precyzji nie potęgować niechlujnością formułowania myśli i nieumiejętnością rozumowania" (Łukowski 2012, 23). To, czy formułowanie analitycznego opisu rzeczywistości jest zasadne, zależy od spełnienia wielu warunków, których część opisałem już wcześniej.

\section{NIETYPOWE WYPOWIEDZI O STANIE FAKTYCZNYM}

Niekiedy kontrolerzy spotykają się z sytuacjami nietypowymi, rodzącymi wątpliwości dotyczące sposobu, a nawet możliwości dokonania opisu. W tym miejscu wymienię cztery z nich. 
1. Ustalanie przyszłego stanu faktycznego. W literaturze o logice wyodrębniono tzw. „ustalenia prognostyczne” - orzekające o przyszłych stanach w badanej działalności (Dobrowolski 2003, 22) ${ }^{41}$. Można by je podzielić na dwa typy: a) niepewne (o momencie asercji $<1), b$ ) pewne (o momencie asercji $=1$ ).

Według orzecznictwa NIK, jeżeli jest to uzasadnione, Izba może wypowiadać się co do potencjalnego skutku stwierdzonej nieprawidłowości (uchwała Zespołu Orzekającego Komisji Rozstrzygającej NIK z 23 maja 2016 r., KPK-KPO.443.043.2016, 15-16.) ${ }^{42}$, a także sformułować ocenę w oparciu o skutki, które mogą wystąpić w przyszłości (uchwała Zespołu Orzekającego Komisji Rozstrzygającej NIK z 8 lipca 2015 r., KPK-KPO.443.123.2015, 6) ${ }^{43}$. Osobiście zalecam ostrożność przy dokonywaniu niepewnych ustaleń prognostycznych, jako że wspomniane orzecznictwo NIK wyraźnie zaznacza, że w postępowaniu kontrolnym nie ma miejsca na „spekulacje związane z działalnością kontrowanych jednostek" (uchwała Zespołu Orzekającego Komisji Rozstrzygającej NIK z 16 kwietnia 2015 r., KPK-KPO.443.028.2015, 13) ${ }^{44}$. W rzeczy samej, wypowiedź spekulatywna to wypowiedź oderwana od rzeczywistościcis, a więc - jako niekorespondująca $\mathrm{z}$ rzeczywistością - stanowi zaprzeczenie prawdy materialnej. Bądź co bądź, fakt to zaistniały stan rzeczy, stąd ex definitione nie jest nim zdarzenie, które się jeszcze nie zdarzyło. Pomimo zalecanej wstrzemięźliwości dopuszczam - o ile poprawne rozumowanie to uzasadnia - przewidywanie przyszłych faktów, a nawet formułowanie na tej podstawie nieprawidłowości ${ }^{46}$, choć orzecznictwo NIK wciąż nie jest do tego przekonane ${ }^{47}$.

${ }^{41}$ Autor ten wyróżnia ponadto ustalenia diagnostyczne (określające istniejący stan faktyczny badanego zjawiska) i ustalenia terapeutyczne (określające, jakie działania należy podjąć, aby doprowadzić do zmian pozytywnych badanej rzeczywistości).

${ }^{42}$ Zespół Orzekający uznał za zasadne stwierdzenie potencjalnego skutku nieprawidłowości sformułowanego za pomocą wyrażenia „mogło mieć wpływ”.

${ }^{43}$ Zespół Orzekający zaaprobował to, że kontrolujący sformułowali swoją ocenę w oparciu nie o skutki zaistniałe w badanym okresie, lecz o skutki które mogą wystąpić w przyszłości i w tym też kontekście została sformułowana przez nich ocena dotycząca niewystarczającego nadzoru ze strony.

${ }^{44}$ Zespół Orzekający odrzucił wniosek składającego zastrzeżenia o dopisanie do treści wystąpienia pokontrolnego przypuszczenia o możliwych skutkach przyjętego w jednostce kontrolowanej systemu uzasadniając to tym, że w postępowaniu zmierzającym do ustalenia stanu faktycznego i jego oceny nie ma miejsca na spekulacje związane z działalnością kontrolowanych jednostek i w treści wystąpienia nie ma miejsca na domniemane skutki rozwiązań przyjętych przez kontrolowanego.

${ }^{45}$ Jedną z definicji słowa „spekulatywny” jest „oderwany od rzeczywistości” (Szymczak 1985, 286).

${ }^{46}$ Sytuacja taka może dotyczyć ustalenia co do gospodarności umowy jeszcze w trakcie jej realizacji, por. przykład podany przeze mnie w artykule (Murat 2019, 23-24).

${ }^{47}$ Kategoryczne formułowanie nieprawidłowości „wzbudziło wątpliwości” rozstrzygających m.in. z tego powodu, że odnosiło się do zdarzenia przyszłego (ryzyka niezrealizowania inwestycji). Zespół Orzekający stwierdził, że możliwe jest jedynie zwrócenie uwagi na takie zagrożenie: 
2. Ustalanie alternatywnego stanu faktycznego. Niekiedy nie sposób poznać z wystarczającym przekonaniem konkretnych faktów, albowiem z dowodów niezbicie wynika, że rzeczywistość mogła być albo $\mathrm{x}$ albo $\mathrm{y}^{48}$. Opory budzi brak poznania konkretnego stanu rzeczywistego, który był przecież jeden. Tym samym jeden z opisów musi być fałszywy.

Uważam, że obawy te są przesadzone i nie ma przeszkód, aby opisać stan faktyczny w formie alternatywnej. Co więcej, akceptuję nawet stwierdzanie prawidłowości i nieprawidłowości, jeżeli oba alternatywne stany faktyczne jednocześnie zaliczają się do stanu prawidłowego bądź nieprawidłowego.

3. Ustalanie prawdy o nieistnieniu jakiegoś zjawiska/zdarzenia czy bytu. Stan faktyczny składa się zarówno ze zdarzeń, jak i z ich braku. W wielu przypadkach wynikają one z siebie logicznie. Na przykład stwierdzenie, że „W pomieszczeniu znajduje się 18 krzeseł” oznacza, że nie ma tam ich więcej. W praktyce kontrolerskiej częstą trudnością jest udowodnienie czegoś, co nie istnieje. W wielu przypadkach kontroler po prostu musi zdać się na kontrolowanego i przedstawiane przez niego dowody określonego stanu faktycznego (zwłaszcza faktu nieistnienia). I tak, ustalając liczbę „,długopisów” kontroler z reguły zda się na dowody przedstawione przez kontrolowanego i trudno od niego oczekiwać, że będzie przeszukiwał pomieszczenia w celu potwierdzenia tego, że nie ma ich więcej. Z powodów metodologicznych poznanie nieistniejącego stanu faktycznego obarczone jest stosunkowo dużą niepewnością. Szczególną ostrożność powinno się zachować podczas ustalania nieistnienia określonego zdarzenia wskazującego na nieprawidłowość. Przykładem jest kontrola z 2015 r., w której NIK pierwotnie stwierdziła nieprawidłowość polegającą na niezamieszczeniu informacji o dwóch projektach w BIP kontrolowanego urzędu. Podstawą ustalenia takiego właśnie stanu faktycznego były wyjaśnienia pracownika. Tymczasem w zastrzeżeniach kierownik tej jednostki przedstawił dowody jednoznacznie wskazujące na zamieszczenie w BIP informacji o jednym z projektów, co doprowadziło do uwzględnienia zastrzeżenia (uchwała Zespołu Orzekającego Komisji Rozstrzygającej NIK z 7 października 2015 r., KPK-KPO.443.172.2015, 3).

4. Ustalanie prawdy o bytach niematerialnych. Do kategorii „,bytów niematerialnych" zaliczam zjawiska, które niekoniecznie pozostawiają ślad w postaci obiektywnie weryfikowalnych obiektów materialnych (chodzi mi o myśli rozumiane jako czyny; por. Heller 2015, 9-15).

Unikanie pozostawiania śladów swojej działalności jest niekiedy świadomą taktyką kontrolowanych, którzy liczą na to, że wobec braku dowodów, kontrolujący odstąpi od formułowania wypowiedzi opisujących niewygodną dla nich

uchwała Zespołu Orzekającego Komisji Rozstrzygającej NIK z 25 marca 2016 r., KPKKPO.443.035.2016, 33.

${ }^{48}$ Chodzi o możliwość zaistnienia dwóch różnych stanów faktycznych niebędących swoją negacją, ponieważ wówczas rozróżnienie nie miałoby sensu. 
rzeczywistość. Mogą w ten sposób znacząco utrudnić na przykład ustalenie, czy przed podjęciem decyzji dokonywali wszechstronnej analizy okoliczności mających wpływ na decyzję.

\section{FILOZOFOWANIE O PRAWDZIE KONTROLERSKIEJ}

Dotychczasowy dyskurs kontroli państwowej mniej lub bardziej świadomie omijał ontologiczne i epistemologiczne aspekty kontroli jako fenomenu prawnego. Uważam to za istotną lukę, lecz dostrzegam w tym też pewien potencjał. Próby jej wypełnienia mogą się przyczynić do większego zainteresowania kontrolą jako przedmiotem filozofowania, a nawet do ukonstytuowania nowego nurtu filozoficznego w ramach filozofii prawa. Osobiście jestem bliższy podejściu „od prawa ku filozofii”, aniżeli od „filozofii ku prawu”, a wynika to z faktu, że czuję się bardziej prawnikiem niż filozofem. Przedstawiając swoje poglądy na problematykę prawdy w kontroli nie chciałbym afirmować jakiejś konkretnej koncepcji teoretycznej ani filozoficznej.

Patrzenie na kontrolę z pozycji filozofa może również doprowadzić do ciekawych wniosków, zwłaszcza w warunkach swobodnej, dyskursywnej refleksji podejmowanej z różnych punktów widzenia. Jak wiadomo, filozofowie zajmowali się definiowaniem prawdy już od czasów starożytnych. Samo tylko wymienienie wielości podejść do prawdy wymagałoby osobnego opracowania. Uderzające jest natomiast stosunkowo małe zainteresowanie prawdą w obszarze teorii i filozofii prawa, co Jerzy Zjadało i Kamil Zaidler wyjaśniają ambiwalentnym stosunkiem prawników do prawdy w ogóle (Zajadło, Zaidler 2013, 294).

\section{PODSUMOWANIE}

Odkrywanie prawdy to niezbywalna cecha każdej praworządnej kontroli. Zasada prawdy materialnej nakazuje ustalać stan faktyczny takim, jakim był w rzeczywistości, uwzględniając jak najwięcej dowodów. Jednak zbytnie skupianie się na idealizacyjnym aspekcie tej zasady grozi nabyciem mylnego przekonania, że podmioty kontrolujące mają obowiązek ustalania prawdy w sposób absolutnie doskonały, ponieważ alternatywą jest kłamstwo.

Tymczasem odkrywanie prawdy wiąże się z pewnego rodzaju kreacją rzeczywistości, którą nazwałem - analogicznie do prawdy sądowej - prawdą kontrolerską. Choć pretenduje ona do odzwierciedlania prawdy, to z natury rzeczy jest niedoskonałym opisem często złożonych zjawisk. Jak bowiem wszystkie wypowiedzi o rzeczywistości, również dokonane w trakcie kontroli ustalenia stanu faktycznego tworzą własną rzeczywistość (rzeczywistość językową), która jest poniekąd subiektywna. Bynajmniej nie musi być jednak kłamstwem. 
Po drugie, prawda kontrolerska jest w mniejszym lub większym stopniu prawdą niepewną. Wręcz nieuniknione są „kompromisy z prawdą”, rozumiane jako akceptowanie określonej niepewności względem poznania prawdy. Czasami wystarczające jest poznanie prawdy przybliżonej, a więc w jakimś stopniu nieznanej. Uczciwy podmiot kontrolujący nie może dawać gwarancji absolutnej prawdziwości opisu stanu faktycznego, lecz co najwyżej gwarancję określonego prawdopodobieństwa jego prawdziwości. Być może niektórym osobom trudno się z tym zgodzić, co wydaje się zrozumiałe w świetle tego, że - jak zauważył Michał Heller - jednym z najsilniejszych intelektualnych instynktów człowieka jest instynkt dążenia do całkowitej pewności (Heller 2015, 91).

Po trzecie, prawda kontrolerska jest w mniejszym lub większym stopniu prawdą uproszczona. Komunikatywność opisu oraz ograniczenia prawne wymuszają prezentowanie jedynie części poznanej prawdy. Prawda kontrolerska ma wobec tego charakter prawdy niepełnej, co samo w sobie jej nie deprecjonuje, albowiem fragmentaryczność nie przesądza o fałszywości opisu.

Po czwarte, prawda kontrolerska funkcjonuje w przestrzeni normatywno-semantycznej. Opisy stanu faktycznego dokonywane są za pomocą języka prawnego i powstają $\mathrm{w}$ określonej procedurze. Może to niekiedy doprowadzić do formułowania niezgodnych ze sobą ustaleń prawdy, lecz obowiązujących formalnie w systemie prawa.

Jak widać, mamy do czynienia z wielopłaszczyznowym zjawiskiem, zarówno prawnym, jak i filozoficznym, a nawet psychicznym. Warto mieć świadomość, że prawda kontrolerska nie jest dana raz na zawsze, lecz ciągle się staje. Bywa podatna na deformacje i łatwo może przeistoczyć się w swoje zaprzeczenie, przy czym najgorszą tego postacią jest prawda pozorna. Jednak wraz ze zgłębianiem jej natury mają szansę udoskonalić się metody ustalania stanu faktycznego. Uwidacznia się zwłaszcza potrzeba ukonstytuowania filozofii kontroli - dyscypliny, której przedmiotem byłaby dojrzała, dyskursywna refleksja nad kontrolą. Taki wyodrębniony dział filozofii mógłby stanowić przestrzeń do podejmowania elementarnych rozważań o granicach kontrolerskiego poznania prawdy. Warto bowiem wiedzieć - albo przynajmniej poszukiwać odpowiedzi - na ile kontrola w ogóle jest $\mathrm{w}$ stanie zaspokoić naturalną potrzebę pewności prawdy i w związku z tym, na ile realne są oczekiwania, aby prawda kontrolerska była w pełni nasycona prawdą. Filozofia kontroli ukazałaby, jak subtelna może być różnica pomiędzy obrazem rzeczywistości a jej obrazą.

Wobec tego, ile było tych krzeseł?

\section{BIBLIOGRAFIA}

Ampuła, Dariusz. 2014. „Kontrola i audyt wewnętrzny w jednostce organizacyjnej”. Problemy Techniki Uzbrojenia 4(132): 17-27.

Antoniak, Marcin. 2012. Kontrola rzadowa w administracji publicznej. Poradnik dla kontrolujacych i kontrolowanych. Warszawa: Wydawnictwo C.H. Beck. 
Bolek, Tomasz. Dorota Rosińska. 2012. „Kontrola w administracji rządowej”. Kontrola Państwowa 1: $35-54$.

Ciołek, Maciej. 2017. „Professional skepticism in auditing and its characteristics”. Prace Naukowe Uniwersytetu Ekonomicznego we Wroctawiu 474: 33-40.

Dobrowolski, Zbysław. 2003. Teoretyczne podstawy kontroli. Zielona Góra: Wydawnictwo Organon. Gizbert-Studnicki, Tomasz. 2009. „Prawda w postępowaniu cywilnym”. Państwo i Prawo 7: 5-19. Heller, Michał. 2015. Moralność myślenia. Kraków: Copernicus Center Press.

Jagielski, Jacek. 2007. Kontrola administracji publicznej. Warszawa: LexisNexis.

Jarzęcka-Siwik, Elżbieta. Bogdan Skwarka. 2011. Najwyższa Izba Kontroli. Komentarz do ustawy o Najwyższej Izbie Kontroli. Warszawa: Wydawnictwo Difin.

Jarzęcka-Siwik, Elżbieta. Bogdan Skwarka. 2012. „Postępowanie kontrolne NIK po nowelizacji - najważniejsze zmiany”. Kontrola Państwowa 4: 23-44.

Jarzęcka-Siwik, Elżbieta. Maciej Berek. Bogdan Skwarka. Zbigniew Wrona. 2018. Najwyższa Izba Kontroli i prawne aspekty funkcjonowania kontroli państwowej. Warszawa: Wydawnictwo NIK.

Jodłowski, Jerzy. Zbigniew Resich. Jerzy Lapierre. Teresa Misiuk-Jodłowska. 1997. Postępowanie cywilne. Warszawa: Wydawnictwo Prawnicze PWN.

Kaczyński, Lech. 2010. „Obowiązki pracowników Najwyższej Izby Kontroli”. Kontrola Państwowa 2 (wydanie specjalne): 77-86.

Kałużny, Stanisław. 2016. Kontrola wewnętrzna. Teoria i praktyka. Warszawa: Polskie Wydawnictwo Ekonomiczne.

Kowalski, Dariusz. 2017. „Zakaz reformationis in peius w postępowaniu przed komisją rozstrzygającą zastrzeżenia do wystąpienia pokontrolnego NIK". Kontrola Państwowa 3: 8-36.

Łukowski, Łukasz. Bartosz Żukowski. 2014. „Zasady tzw. 'prawdy materialnej' i 'prawdy formalnej’. Analiza logiczno-filozoficzna i przeglądowa”. Acta Universitatis Lodziensis. Folia Iuridica 73: 49-61.

Łukowski, Piotr. 2012. Logika praktyczna z elementami wiedzy o manipulacji. Warszawa: Wolters Kluwer.

Murat, Leszek. 2016. „Stosunek kontrolnoprawny - relacje prawne między kontrolującymi a kontrolowanymi". Kontrola Państwowa 3: 8-21.

Murat, Leszek. 2017. „Zasady kontroli jako szczególne zasady prawa regulujące funkcjonowanie systemu kontroli”. Kwartalnik Prawa Publicznego 4: 37-54.

Murat, Leszek. 2019. „Kryterium gospodarności”. Kontrola Państwowa 12: 10-28.

Najwyższa Izba Kontroli. 2016. Standardy ISSAI 100. ISSAI 200. ISSAI 300. ISSAI 400. Publikacja Międzynarodowej Organizacji Najwyższych Organów Kontroli. Warszawa: Wydawnictwo NIK.

Nawłoka-Bielecki, Czesław. 1991. [Niepublikowany materiał szkoleniowy]. Podstawowe zasady i tryb postępowania kontrolnego. Warszawa.

Nowikowska, Monika. Janusz Cieślak. 2015. „O potrzebie zmian w ustawie o kontroli w administracji rządowej - uwagi de lege ferenda". Kontrola Państwowa 4: 183-189.

Padrak, Rafał. 2003. „Zasady postępowania kontrolnego Najwyższej Izby Kontroli”. Kontrola Państwowa 2003: 24-52.

Padrak, Rafał. 2012. Postepowanie kontrolne NIK. Komentarz. Wrocław: Presscom.

Podręcznik kontrolera Najwyższej Izby Kontroli. 2002. [Niepublikowany]. Najwyższa Izba Kontroli.

Robaczyński, Wojciech. 2003. „Wybrane zagadnienia postępowania odwoławczego w NIK (Głos w dyskusji na marginesie artykułu R. Padraka)". Kontrola Państwowa 1: 26-37.

Sordyl, Tomasz. 2019. „Oględziny w postępowaniu kontrolnym”. Przeglad Metodyczny 2: 19-30.

Sordyl, Tomasz. 2019. „Przesłuchanie świadka w postępowaniu kontrolnym”. Przegląd Metodyczny 2: $3-18$.

Stępiński, Jerzy. 1969. „Jeszcze o fakcie kontrolnym”. Kontrola Państwowa 3. 
Sylwestrzak, Andrzej. 2006. Kontrola administracji publicznej w III Rzeczypospolitej Polskiej. Gdańsk: Wydawnictwo Uniwersytetu Gdańskiego.

Sztajerwald, Zygmunt. 1969. „W sprawie normatywnego określenia zasad postępowania w procesie kontroli”. Kontrola Państwowa 2.

Szymanek Jarosław. 2006. „O kontroli państwowej - teoretycznie”. Kontrola Państwowa 5.

Szymczak, Mieczysław. Red. 1985. Słownik języka polskiego. Tom III. Warszawa: Państwowe Wydawnictwo Naukowe.

Widła, Tadeusz. Dorota Zienkiewicz. 2005. Logika. Warszawa: Wydawnictwo C.H. Beck.

Zajadło, Jerzy. Kamil Zaidler. 2013. Filozofia prawa w pytaniach i odpowiedziach. Warszawa: LexisNexis.

\section{Akty prawne}

Ustawa z dnia 7 października 1992 r. o regionalnych izbach obrachunkowych (Dz.U. z 2016 r., poz. $561 \mathrm{ze} \mathrm{zm}$.).

Ustawa z dnia 23 grudnia 1994 r. o Najwyższej Izbie Kontroli (Dz.U. z 2019 r., poz. 489 ze zm.).

Ustawa z dnia 6 czerwca 1997 r. Kodeks karny (Dz.U. z 2018 r., poz. 1600 ze zm.).

\section{Orzecznictwo}

Uchwała Kolegium NIK z dnia 26 października 2016 r., KPK-KPO.000.045.2016. [Niepublikowana]. Uchwała Zespołu Orzekającego Komisji Rozstrzygającej NIK z 16 kwietnia 2015 r., KPKKPO.443.028.2015. [Niepublikowana].

Uchwała Zespołu Orzekającego Komisji Rozstrzygającej NIK z 8 lipca 2015 r., KPKKPO.443.123.2015. [Niepublikowana].

Uchwała Zespołu Orzekającego Komisji Rozstrzygającej NIK z 7 października 2015 r., KPKKPO.443.172.2015. [Niepublikowana].

Uchwała Zespołu Orzekającego Komisji Rozstrzygającej NIK z 21 marca 2016 r., KPKKPO.443.029.2016. [Niepublikowana].

Uchwała Zespołu Orzekającego Komisji Rozstrzygającej NIK z 25 marca 2016 r., KPKKPO.443.035.2016. [Niepublikowana].

Uchwała Zespołu Orzekającego Komisji Rozstrzygającej NIK z 23 maja 2016 r., KPKKPO.443.043.2016. [Niepublikowana].

\section{Leszek Murat}

\section{THE AUDIT TRUTH}

Abstract. Each lawful audit centers on discovering truth. Often times, revealing facts is far from ideal and entails some kind of truth creation, called by the author "the audit truth". The audit statements of facts create their own normative and semantic reality. The audit truth is always to some degree subjective, uncertain, approximated and simplified. Nonetheless, it does not make it false. Imperfectness of reality's description is hard to avoid. As such it has to be accepted only if it meets certain standards of discovery and description. The article, by revealing the nature of the audit truth, fills the gap in the literature that so far has been focused on the principle of the material truth as an ideal goal for auditors. The author argues that pursuing truth in audit deserves advanced and systematic studies by audit philosophy.

Keywords: audit truth, objective truth, substantive truth, formal truth, legal truth, audit philosophy. 